\title{
Microorganism population in two-phase anaerobic fermentation of separated liquid of dairy manure
}

\author{
Qiang Li, Zhengjun Guan*, Guoxiang Zheng \\ (College of Engineering, Northeast Agricultural University, Harbin 150030, China)
}

\begin{abstract}
In order to reduce incomplete fermentation caused by high substrate viscosity and low mass transfer efficiency during fermentation process, batch and two-phase anaerobic fermentation experiments were conducted in this study. Dairy manure was separated by using solid-liquid separator firstly. Separated liquid (SL) and diluted dairy manure (DDM) as raw materials were evaluated in terms of gas production performance for both batch and two-phase anaerobic fermentation. The microorganism population was characterized by scanning electron microscope (SEM) and Denaturing Gradient Gel Electrophoresis (DGGE). The results showed that Volatile Solid (VS) methane yield of SL was $124.51 \mathrm{~L} / \mathrm{kg}$ VS, which was 2.09 times higher than that of DDM $(59.50 \mathrm{~L} / \mathrm{kg}$ VS) in batch anaerobic fermentation. The Bacteroides and Veillonella with higher activity were the majority microorganism population in acidogenic phase, whereas the Firmicutes and Corynebacterium with methanogenic properties became the predominant microorganism population in methanogenic phase. This study achieved the phase separation and improved the gas production performance.
\end{abstract}

Keywords: separated liquid, diluted dairy manure, two-phase anaerobic fermentation, microorganism, scanning electron microscope (SEM), Denaturing Gradient Gel Electrophoresis (DGGE)

DOI: $10.25165 /$ j.ijabe.20181101.3206

Citation: Li Q, Guan Z J, Zheng G X. Microorganism population in two-phase anaerobic fermentation of separated liquid of dairy manure. Int J Agric \& Biol Eng, 2018; 11(1): 206-211.

\section{Introduction}

With the rapid development of Chinese livestock industry, the environmental pollution caused by livestock and poultry gains more attention. Waste heap and discharge have a direct or indirect negative impact on water, air and soil for human health and ecosystems ${ }^{[1-3]}$, as well as the wasting of organic matter. Anaerobic fermentation is an effective approach to transfer livestock and poultry waste to energy and value-added products. Anaerobic fermentation is a metabolic process regulated by a variety of functional microorganisms, whose diversity and dynamic changes are most influential factors ${ }^{[4]}$. Therefore, the comprehensive monitoring and deep analysis of microorganisms will improve the understanding of anaerobic fermentation for better stabilization of the fermentation system. However, traditional method was not able to monitor process completely due to the complexity and the quantity of microorganisms ${ }^{[5]}$.

Denaturing Gradient Gel Electrophoresis (DGGE) is one of molecular biology method based on the different concentrations of denaturant in electrophoresis. In this method, the DNA double strands with the same length but different base sequence is dissociated at the corresponding concentration gradient. After the silver staining, DNA fragments with different sequence are separated on the gel with different strength ${ }^{[6-8]}$. Therefore, DGGE is considered a favor method to reveal the microbial community

Received date: 2017-01-13 Accepted date: 2017-10-16

Biographies: Qiang $\mathbf{L i}, \mathrm{PhD}$ candidate, research interests: biomass transformation and energy utilization, Email: 1q4325356@163.com; Guoxiang Zheng, Professor, research interests: biomass transformation and microorganism utilization, Email: $99036951 @$ qq.com.

*Corresponding author: Zhengjun Guan, Professor, research interests: biomass transformation and energy utilization. Northeast Agricultural University, No.59 Mucai Street, Xiangfang District, Harbin 150030, China. Tel: +8613351115923, Fax: +86 45155190608, Email: zhjguan@163.com. structure and monitor the microbial species dynamics ${ }^{[9]}$.

Shi et al. ${ }^{[10]}$ used DGGE to study microbial species and dominant species of anaerobic fermentation, and found that microbial species and dominant species had changed in different fermentation periods. Wang et al. ${ }^{[11]}$ used DGGE to investigate the methanogenic archaea species in the low-temperature biogas digesters and analyze the changes of the dominant species before and after fermentation. The results showed that the dominant species of methanogenic archaea produced in different biogas samples differed from each other before and after low-temperature fermentation.

Two-phase anaerobic fermentation offers many advantages such as large organic load, high fermentation stability, short hydraulic retention time (HRT) and high gas production efficiency comparing with single-phase anaerobic fermentation ${ }^{[12,13]}$. Traditional anaerobic fermentation of livestock and poultry waste focus on high-concentration (TS is more than 9\%), which generates other issues: high substrate viscosity and low mass transfer efficiency leading to incomplete fermentation. In this study, separated liquid (SL) separated using solid-liquid separator to significantly reduce its concentration. The separated solids were reutilized ${ }^{[14-19]}$ and SL was disposed to produce biogas through two-phase anaerobic fermentation $^{[20]}$. The microorganism population of two-phase anaerobic fermentation was investigate using DGGE, indicating the selectivity of microorganisms was separated when two-phase anaerobic fermentation of SL with the $6.6 \%$ of TS concentration. Finding in this study will fill the gap in literature and generate important knowledge leading to comprehensive utilization of dairy manure.

\section{Materials and methods}

\subsection{Materials}

Dairy manure used in this study was provided by Wandashan 
Dairy Cattle Breeding Base of Harbin, China. Dairy manure was diluted with water at 2:1 mass ratio. SL was obtained by separating diluted dairy manure using a solid-liquid separator (DN140) invented by our laboratory. The inoculum was collected from an anaerobic continuous fermentation digester in our laboratory. The scanning electron microscopic (SEM) images of SL and diluted dairy manure (DDM) referring to non-separated diluted manure are shown in Figure 1. Table 1 summarizes the parameters of raw materials including TS, VS, lignocellulose, viscosity and carbon and nitrogen $(\mathrm{C} / \mathrm{N})$ ratio before anaerobic fermentation. SL shows significant lower lignocellulose content, viscosity and $\mathrm{C} / \mathrm{N}$ ratio comparing to DDM with similar VS, indicating that SL provided better conditions for microorganisms activity than DDM.

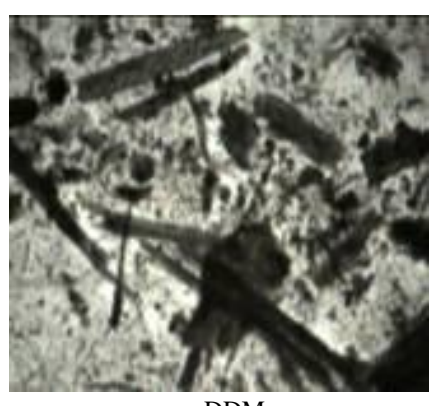

a. DDM

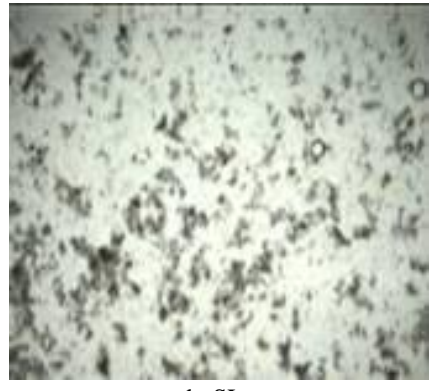

b. SL
Figure 1 Scanning electron microscopic image of DDM and SL

Table 1 Parameters of raw materials

\begin{tabular}{cccccc}
\hline & TS/\% & VS/\% & Lignocellulose* & Viscosity/mPa.s & C/N ratio \\
\hline DDM & $5.79 \pm 0.12$ & $4.86 \pm 0.21$ & $57.66 \pm 0.87$ & $237 \pm 23$ & 40.12 \\
SL & $6.60 \pm 0.01$ & $4.98 \pm 0.09$ & $37.70 \pm 1.32$ & $182 \pm 10$ & 18.79 \\
Inoculum & $4.37 \pm 0.03$ & $3.09 \pm 0.06$ & $35.38 \pm 0.85$ & $124 \pm 4$ & 18.26 \\
\hline
\end{tabular}

Note: $*$ is $\%$ of TS

\subsection{Experimental devices and conditions}

Experimental devices of anaerobic fermentation are shown in Figures 2 and 3, respectively. The devices were composed of the temperature control part, the fermentation part and the gas gathering part. The volume of daily biogas generated was calculated based on the downward displacement of water. The effective volume of the fermentation tank was $4.5 \mathrm{~L}$. Batch anaerobic fermentation was conducted at $(5 \pm 2)^{\circ} \mathrm{C}$ for $20 \mathrm{~d}$ using $70 \%$ raw materials and $30 \%$ inoculations. Two-phase anaerobic fermentation experiment was carried out at medium temperature of $(35 \pm 2)^{\circ} \mathrm{C}$. The TS of SL was $6.6 \%$, the HRT of the acidogenic phase was $3 \mathrm{~d}$, the HRT of the methanogenic phase were $6 \mathrm{~d}$ and $7 \mathrm{~d}$, respectively, and subsequent fermentation $1 \mathrm{~d}$. According to HRT of methanogenic, acidic liquid was transmitted quantitatively to the methane production tank of the start-up requirements using peristaltic pump ${ }^{[20]}$.

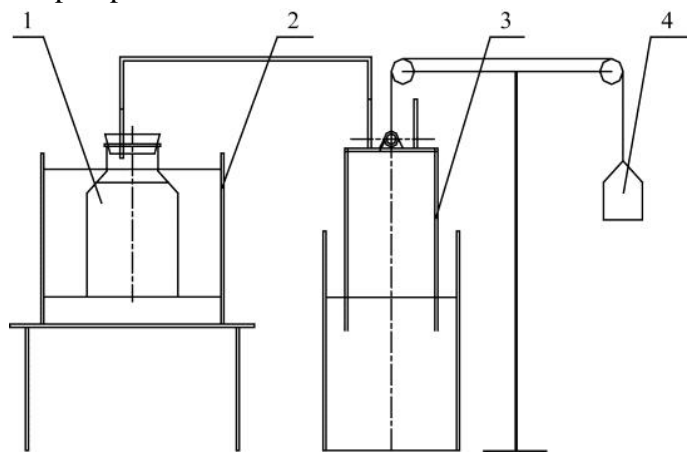

$\begin{array}{lll}\text { 1. Fermentation tank } & \text { 2. Water bath } 3 \text {. Gas gathering tank } \quad \text { 4. Counter weight }\end{array}$ Figure 2 Experimental device of batch anaerobic fermentation

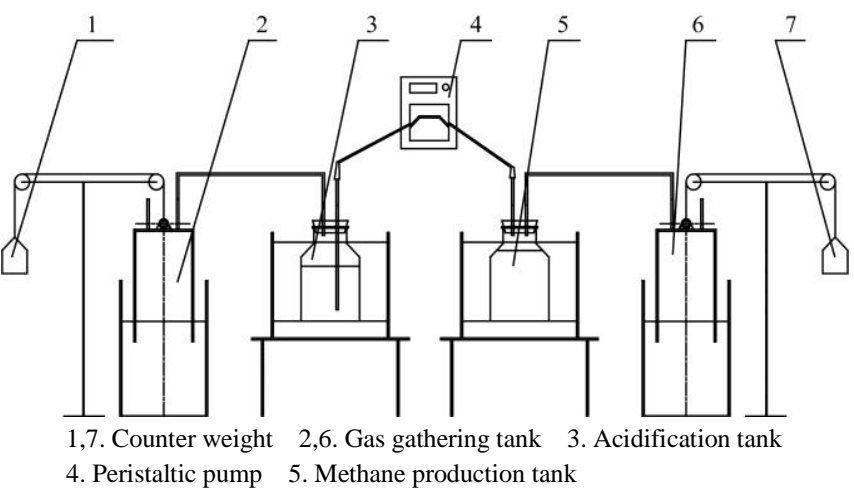

Figure 3 Experimental device of two-phase anaerobic fermentation

\subsection{Experimental methods}

\subsubsection{Anaerobic fermentation}

In this study, the SL and DDM of batch anaerobic fermentation were evaluated firstly; afterwards the SL indicators of two-phase anaerobic fermentation were analyzed including the acidification characteristics, the start-up time of methanogenic phase, the different HRT calculated by the load of in-out materials, and the gas production performance. The microorganism population was analyzed by SEM, and DGGE. TS, VS and ash content were determined according to standard methods ${ }^{[21]}$. The $\mathrm{pH}$ was measured by HI9224 (Hanna Inc., Italy); the volume and composition of gas were measured by GC-6890N (Agilent Inc., USA); the total carbon was measured by VarioTOC (Elementar Inc., Germany); the total ammonia nitrogen and total nitrogen were measured by Kjeltec2300 (FOSS Inc., Denmark). All of the measurements were conducted in triplicate, and the averaged data are presented.

\subsubsection{DGGE method}

\section{(1) DNA extraction}

DNA extraction was carried out using Gao Pingping's method $^{[22]}$. The kit (Ezup column genomic DNA extraction kit) was provided by Shanghai Biotechnology Company for purification.

(2) Amplification of variable region of 16SrDNA V3

16SrDNA V3 variable region bacterial specific primers:

P1:5'-CGCCCGCCGCGCGCGGCGGGCGGGGCGGGGGC ACGGGGGGCCTACGGGAGGCAGCAG-3',

5'-ATTACCGCGGCTGCTGG-3'. The primers were supplied by Shanghai Biomedical Engineering Company.

The PCR reaction system consisted of $2.5 \mu \mathrm{L}$ of $10 \times$ PCR buffer $\left(\mathrm{Mg}^{2+}\right.$ free $), 2.0 \mu \mathrm{L} \mathrm{MgCl}_{2}(25 \mathrm{mmol} / \mathrm{L})$, and $2.0 \mu \mathrm{L}$ dNTPs $(2.5 \mathrm{mmol} / \mathrm{L})$. There were $0.1 \mu \mathrm{L}, 1 \mathrm{U}$ Ex Tag enzymes in the upstream and downstream primers. DNA solution of $1 \mu \mathrm{L}(1 \mathrm{mg})$ was filled up to $25 \mathrm{~mL}$ with distilled water. Reaction conditions: denaturation for $4 \mathrm{~min}$ at $94^{\circ} \mathrm{C}$, degeneration for $30 \mathrm{~s}$ at $94^{\circ} \mathrm{C}$, annealing for $30 \mathrm{~s}$ at $55^{\circ} \mathrm{C}$, extension for $1 \mathrm{~min}$ at $72^{\circ} \mathrm{C}$, cycling 30 times, finally extension to $5 \mathrm{~min}$ at $72^{\circ} \mathrm{C}$. After the amplification products were electrophoreticly detected by $1 \%$ agarose gel, they went through 'Reconditioning PCR' to wipe off the heteroduplexes in PCR products ${ }^{[23,24]}$.

(3) DGGE reconditioning

PCR products were separated by DGGE. The polyacrylamide gel with $8 \%$ concentration was converted to buffer solution whose gradients were $35 \%-60 \%, 60^{\circ} \mathrm{C}, 150 \mathrm{~V}, 1 \times \mathrm{TAE}$. The electrophoretic time was 14-16 $\mathrm{h}^{[25]}$. Avoid light dyed for $30 \mathrm{~min}$ by SYBR GREEN, and then rinsed them with deionized water. After staining, the samples were detected and photographed using 
the ALPHA gel imaging system. The software of Quantity One was used to analyze the number of electrophoretic bands, the peak brightness and the mean optical density.

\section{Results and Analysis}

\subsection{Comparison of SL with DDM in batch anaerobic} fermentation

As shown in Figure 4, the peak of gas production of SL occurred earlier than DDM and the high gas period nearly ended on the 13th day. In contrast, the fermentation time of DDM was longer than SL resulting in more gas production at fermentation anaphase. The gas productions of SL and DDM at fermentation period $(20 \mathrm{~d})$ were $21.84 \mathrm{~L}$ and $28.74 \mathrm{~L}$, respectively. The COD removal rate of SL was $65.40 \%$, which was $16.3 \%$ higher than that of DDM. The VS methane yield of SL was $124.51 \mathrm{~L} / \mathrm{kg} \mathrm{VS}, 2.09$ times than that of DDM (59.50 L/kg VS). COD and VS removal rate were calculated based on the influent and effluent COD and VS values (Table 2). These results indicated that SL has better fermentation performance than DDM.

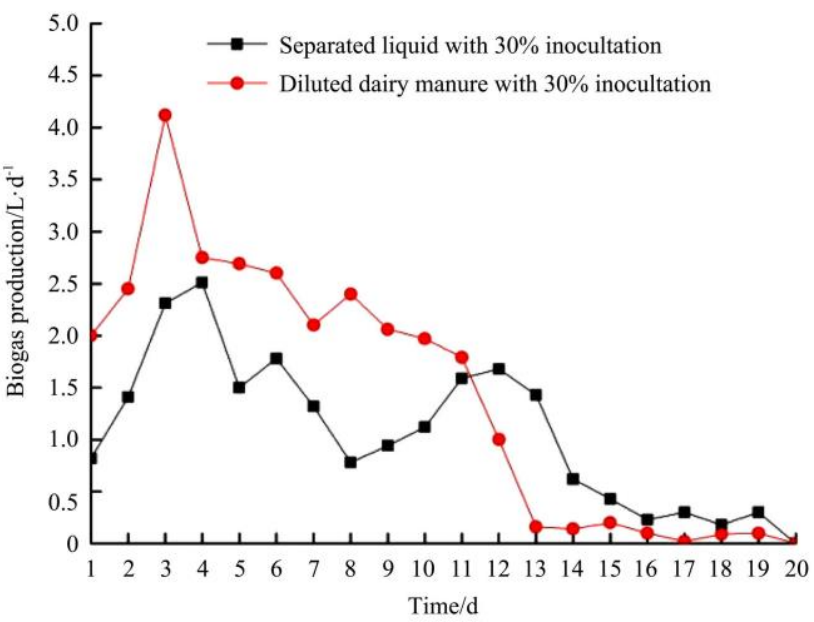

Figure 4 Comparison of daily gas production of DDM and SL in batch anaerobic fermentation

Table 2 Comparison of the anaerobic fermentation performance of DDM and SL

\begin{tabular}{|c|c|c|c|c|c|c|}
\hline & $\begin{array}{c}\text { COD removal rate } \\
1 \%\end{array}$ & $\begin{array}{l}\text { VS removal rate } \\
1 \%\end{array}$ & $\begin{array}{c}\text { Lignocellulose } \\
\text { degradation rate/\% }\end{array}$ & $\begin{array}{c}\text { Methane content } \\
1 \%\end{array}$ & $\begin{array}{l}\text { TS methane yield } \\
/ \mathrm{L} \cdot\left(\mathrm{kg} \mathrm{TS}^{-1}\right.\end{array}$ & $\begin{array}{l}\text { VS methane yield } \\
/ \mathrm{L} \cdot(\mathrm{kg} \mathrm{VS})^{-1}\end{array}$ \\
\hline DDM & 49.10 & 35.19 & 33.57 & $45.90 \pm 0.90$ & 49.94 & 59.50 \\
\hline SL & 65.40 & 44.58 & 37.27 & $73.72 \pm 2.50$ & 93.95 & 124.51 \\
\hline
\end{tabular}

\subsection{Microbial morphology characterization}

SEM was employed to analysis microorganism population during the fermentation process. Microbial morphology of two-phase anaerobic fermentation was observed in methaneogenic phase. The dominant populations of methanogenic phase were Methanobacterium and Methanococcus, such as Methanobacterium sohngenii and Methanosarcina barkeri. As acid concentration decreased, the growth rate of Methanobacterium sohngenii increased. In contrast, as the increase of acid concentration, the growth rate of Methanobacterium sohngenii tended to slow down, while the growth rate of Methanosarcina barkeri increased as acid concentration increased. In addition, its growth rate was very high. When acid was accumulated, Methanosarcina barkeri was able to easily become the dominant population of methanogenic. However, another study has found that the controlling of Methanosarcina barkeri growth was used to improving the efficiency of anaerobic fermentation, because Methanobacterium sohngenii has high affinity to acetic acid and formed particles sludge with better quality. When Methanosarcina barkeri became the dominant population, it has small shape and easily washed out from the reactor. According to the growth and variation rules of Methanosarcina barkeri and Methanobacterium sohngenii, the controlling of the acid concentration was able to yield lower growth rate of Methanosarcina barkeri than that of Methanobacterium sohngenii. High affinity of Methanobacterium sohngenii to substrate was used to develop the dominant population at the low substrate concentration, thus forming good granular sludge, which was beneficial for the methane production rate.

In Figure 5a, multiple microorganism population coexisted in the early stage, whereas Methanococcus was the main bacteria in the latter stage in Figure 5b. While in the methanogenic phase of SL, Methanobacterium sohngenii was the dominated microorganism. The images of microorganism and granular sludge are shown in Figure 6.

\subsection{Analysis on two-phase anaerobic fermentation microorganisms}

Fermentation microorganisms are a group of complicated bacteria, which require different hypoxia degree. They include organic decomposing bacteria and methanogenic bacteria. Organic decomposing bacteria is also known as non-methanogen bacteria, which includes fermentative bacteria, $\mathrm{H}_{2}$-producing acetogens and acetic acid-producing bacteria; methanogen bacteria include hydrogen-eating methanogens and acetic acid-eating methanogens. These microorganisms play different transformation roles as nutritional needs. From complicated organic matter degradation to methane formation, the whole process is completed under their collaboration and interaction with each other.

In this study, microorganism population in the anaerobic fermentation system was dynamically tracked by DGGE. The results are shown in Figure 7. In DGGE map, the number of bands reflects the diversity of microbial species, while the banding intensity reflects the abundance of various biological species. Figure 7a shows the DGGE map of population during the start-up period. Lanes 1-3 represent main microbial between acidogen and methanogen microorganisms in synergistic process. Lanes 4-7 represent the DGGE map of the stage, in which the start-up process has ended and methanogens have become the dominant species. According to the distribution of the bands of the microbial species, the dominant microorganisms are concentrated clearly. The numbers of bands in the lanes are obviously reduced at only four bands, suggesting that two-phase anaerobic fermentation had achieved phase separation. Based on the comparison of bands' sequence (Tables 3 and 4) and the heredity relationship of different microbes in population (Figure 8), there were various microbial species in the acidogenic phase. The dominant microbial species were bacilli and cocci belonging to anaerobic and acid bacteria with higher activity. Meanwhile, there existed some aerobacter aerogenes. In Figure 7a, the similarity rates of the bands 8 and 14 are $100 \%$, and the similarity rates of the bands 13 and 19 are $98 \%$. They represent Bacteroides and Veillonella belonging to the anaerobic bacteria, and they took advantages of complicated organic matter to produce organic volatile acid. Most Bacteroides, such as bacteroid and fusiformis, belong to strict anaerobic bacteria with aerogenesis and acidogenic functions. 


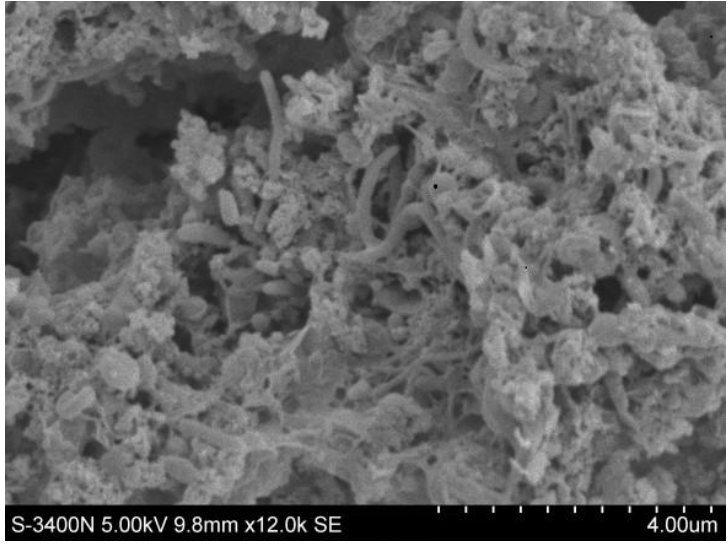

a. Early phase of batch fermentation

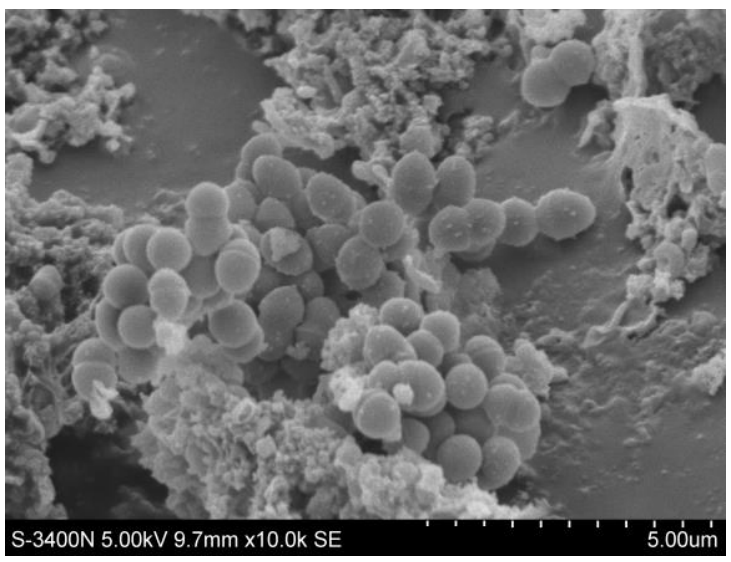

b. Middle phase of batch fermentation

Figrue 5 Microorganism images during the early and middle phases of batch fermentation by dairy manure

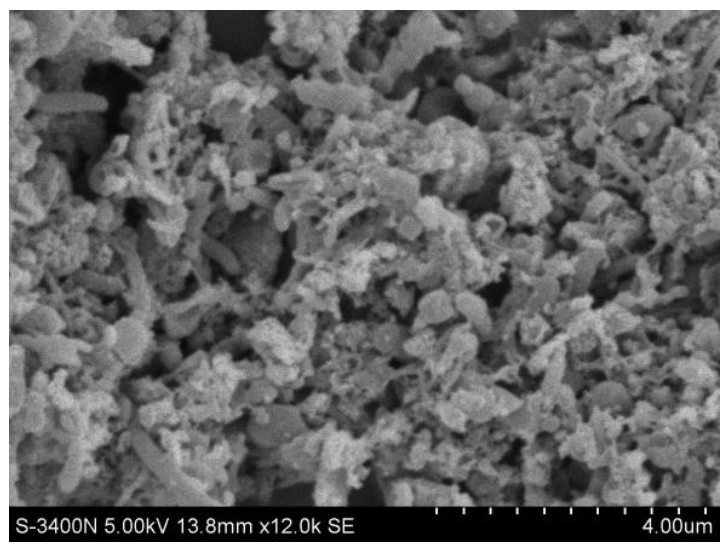

a. HRT $7 \mathrm{~d}$

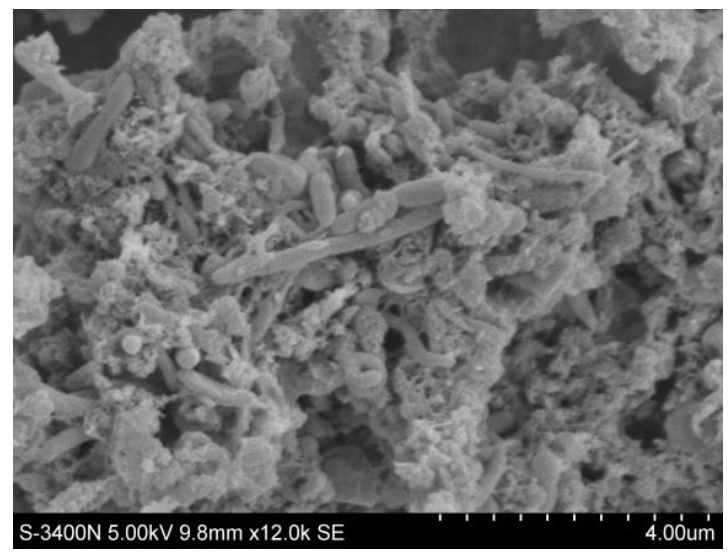

b. HRT $6 \mathrm{~d}$

Figure 6 Methanogenic bacteria images at HRT $7 \mathrm{~d}$ and $6 \mathrm{~d}$
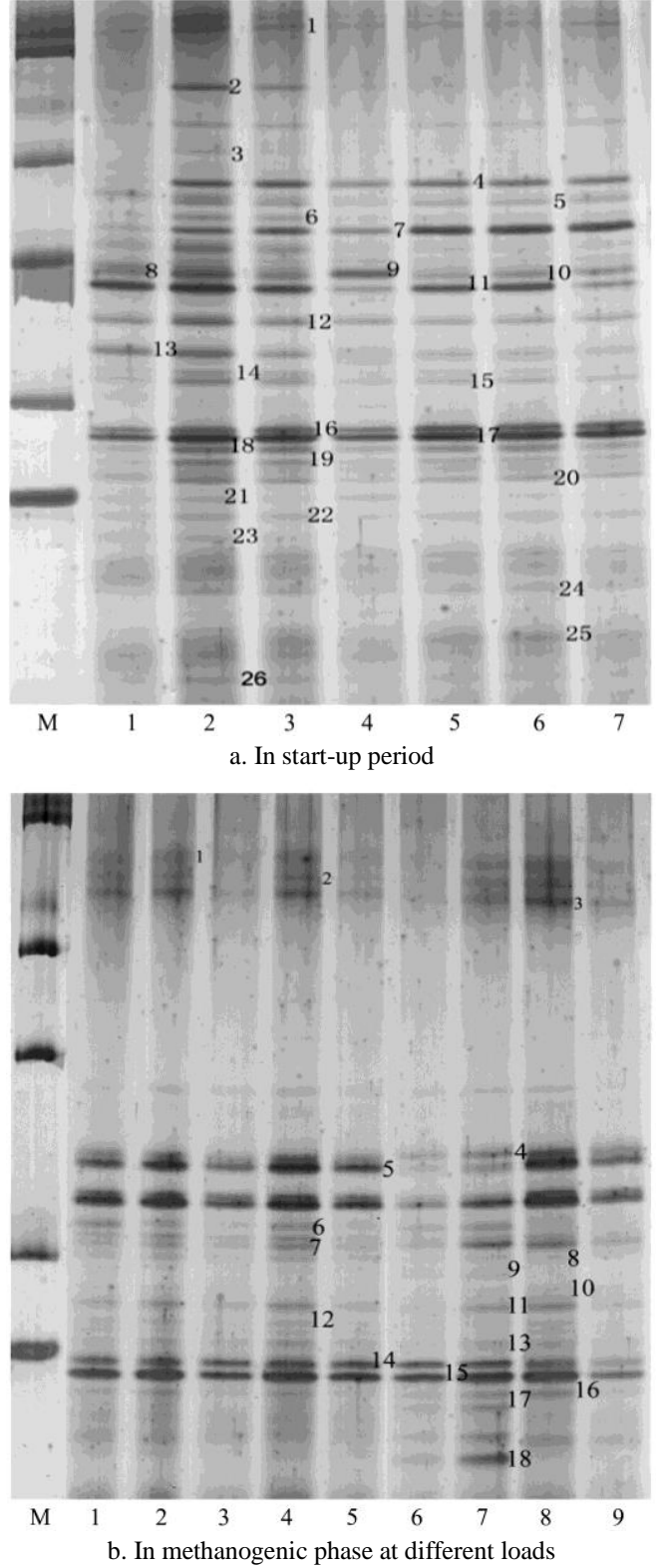

Note: M: mark-DL-2000; a. 1-7: start-up sample; b. 1-5: 1/7 load; 6-7: 1/8 load; 8-9: $1 / 5$ load.

Figure 7 DGGE maps of bacteria in start-up period and in methanogenic phase at different loads

By monitoring the composition of microorganism species in the methanogenic phases, the number and composition of microorganisms species has changed significantly, as shown in Figure $7 \mathrm{~b}$. The number of bands is significantly reduced in lanes 1-9, indicating that the predominant species are 5, 14 and 15 . These three bands represent Enterobacteriaceae, Firmicutes and Corynebacterium, respectively. The composition change of the species indicated that the fermentation conditions and the growth environment of the microorganisms had changed greatly from the acidogenic phase to the methanogenic phase. Microorganisms had to readapt to the methanogenic fermentation environment, resulting in the inhibition of the metabolic activity and the number of acidogen bacteria was significantly decreased. In contrast, after a period of adjustment, methanogen bacteria were domesticated in the methanogenic environment. The quantity and activity of acidogen bacteria were promoted to become the dominant species in the methanogenic phase. The bands 14 and 15 with methanogenic ability represent Firmicutes and Corynebacterium, respectively. The existence of these two types 
of microorganism shows that Firmicutes and Corynebacterium as main methaneogen bacteria used dairy manure as raw material in this study. The results of SEM also confirm that there were a large number of bacillus and cocci in the acidogenic phase during the anerobic fermentation, and they were coordinated to maintain a relatively stable and balanced methanogenic system.

Table 3 Alignment results of different bands in DGGE profile during the start-up stage of methanogenic phase

\begin{tabular}{|c|c|c|c|}
\hline $\begin{array}{l}\text { Band } \\
\text { number }\end{array}$ & Affinis bacterial strain & $\begin{array}{c}\text { GenBank } \\
\text { number }\end{array}$ & $\begin{array}{l}\text { Similarity } \\
\text { rate } / \%\end{array}$ \\
\hline 1 & Uncultured Ruminococcaceae bacterium & EU794262.1 & 100 \\
\hline 2 & Uncultured rumen bacterium & EU850483.1 & 92 \\
\hline 3 & Uncultured Bacterioidetes bacterium & GQ468585.1 & 96 \\
\hline 4 & Flavobacteriaceae str. SW072 & AF493679.1 & 89 \\
\hline 5 & Uncultured Lachnospiraceae bacterium & EF708627.1 & 100 \\
\hline 6 & Pseudomonas sp. D3111 & FJ161242.1 & 98 \\
\hline 7 & Bacteroides finegoldii & EU722740.1 & 92 \\
\hline 8 & Uncultured cercozoan & AB520719.1 & 100 \\
\hline 9 & Chrvseobacterium sp. HMD1043 & GQ259742.1 & 100 \\
\hline 10 & Uncultured Ruminococcaceae bacterium & EU794305.1 & 96 \\
\hline 11 & Clostridium caenicola & AB221372.1 & 95 \\
\hline 12 & Uncultured Bacteroidales bacterium & EU573868.1 & 96 \\
\hline 13 & Uncultured rumen bacterium & GU304029.1 & 98 \\
\hline 14 & Acinetobacter sp. NFM2 & GQ377756.1 & 100 \\
\hline 15 & Pseudonocardiaceae bacterium NBRC 105525 & AB511316.1 & 99 \\
\hline 16 & Bacteroides sp. XB44A & AM230649.1 & 93 \\
\hline 17 & Uncultured Firmicutes bacterium & FJ651403.1 & 100 \\
\hline 18 & Tissierella creatinophila strain DSM 6911 & GQ461823.1 & 97 \\
\hline 19 & Uncultured Lachnospiraceae bacterium & EF708603.1 & 98 \\
\hline 20 & Uncultured Ruminococcaceae bacterium & EU794234.1 & 98 \\
\hline 21 & Bacteroides finegoldii & EU722740.1 & 92 \\
\hline 22 & Pseudoxanthomonas sp.M967 & AY368563.1 & 97 \\
\hline 23 & Uncultured Ruminococcaceae bacterium & EU794305.1 & 96 \\
\hline 24 & Uncultured Bacterioidetes bacterium & GQ468585.1 & 96 \\
\hline 25 & Uncultured Bacterioidetes bacterium & EU573868.1 & 96 \\
\hline 26 & Tissierella creatinophila & GQ461823.1 & 97 \\
\hline
\end{tabular}

Table 4 Alignment results of different bands in DGGE profile during the operation stage of methanogenic phase

\begin{tabular}{clcc}
\hline $\begin{array}{c}\text { Band } \\
\text { number }\end{array}$ & \multicolumn{1}{c}{ Affinis bacterial strain } & $\begin{array}{c}\text { GenBank } \\
\text { number }\end{array}$ & $\begin{array}{c}\text { Similarity } \\
\text { rate/\% }\end{array}$ \\
\hline 1 & Bacteroides finegoldii & EU722740.1 & 93 \\
2 & Uncultured Bacterioidetes bacterium & AM157485.1 & 96 \\
3 & Tissierella creatinophila strain DSM 6911 & GQ461823.1 & 97 \\
4 & Enterococcus silesiaus strain SS1792 & GQ337036.1 & 96 \\
5 & Acholeplasma parvum & AY538170.1 & 89 \\
6 & Leadbetterella byssophila strain 4M15 & AY854022.2 & 92 \\
7 & Chrvseobacterium sp. HMD1043 & GQ259742.1 & 99 \\
8 & Iron-reducing bacterium & FJ269065.1 & 93 \\
9 & Uncultured Ruminococcaceae bacterium & EU794090.1 & 94 \\
10 & Bacteroides sp. & AB003390.1 & 96 \\
11 & Brevibacillus agri strain IHB B 1387 & GU186123.1 & 99 \\
12 & Bacteroides sp. & EU834833.1 & 98 \\
13 & Uncultured cyanobacterium & EF106460.1 & 94 \\
14 & Uncultured Firmicutes bacterium & FJ651041.1 & 100 \\
15 & Corynebacterium sp. ICIRC105 & GQ260084.1 & 100 \\
16 & Phascolarctobacterium sp. YIT 12068 & AB490812.1 & 93 \\
17 & Uncultured rumen bacterium & GU303956.1 & 96 \\
18 & Uncultured Bacteroidales bacterium & EU794094.1 & 96 \\
\hline & & & \\
\hline
\end{tabular}

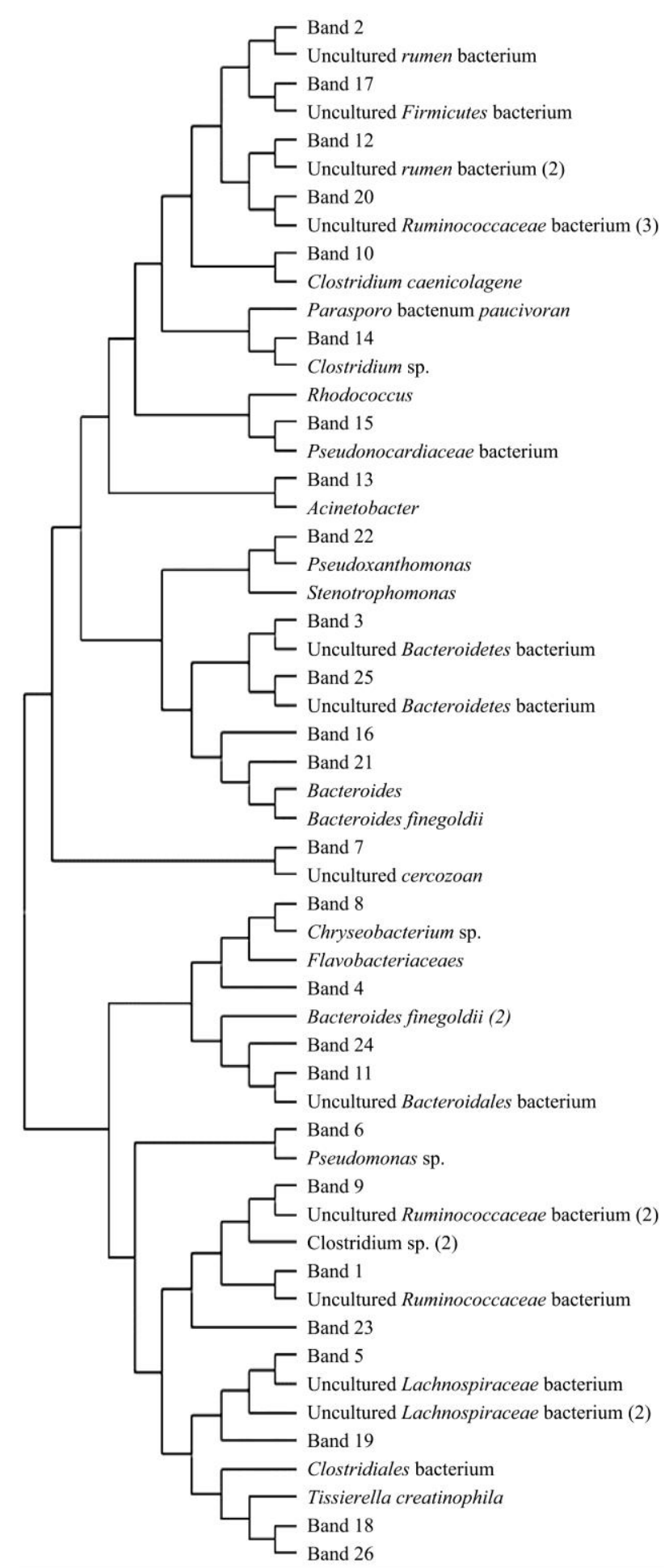

Figure 8 Phylogenetic tree of 16S rDNA excised from DGGE profiles during the start-up process of methanogenic phase

\section{Conclusions}

In batch anaerobic fermentation, the results showed that the lignocellulose content of SL was greatly reduced, the granule radius decreased significantly, and $\mathrm{C} / \mathrm{N}$ was closed to $20: 1$. The COD removal rate of SL was $65.40 \%$, which was $16.3 \%$ higher than that of DDM. The VS methane productivity of SL was $124.51 \mathrm{~L} / \mathrm{kg}$ VS, which was 2.09 times than that of DDM $(59.50 \mathrm{~L} / \mathrm{kg} \mathrm{VS})$. Therefore, SL is a better feedstock for anaerobic fermentation than DDL.

The microorganism species were dynamically tracked by DGGE in acidogenic and methanogenic phases. The results 
showed that both the Bacteroides (uncultured Cercozoan and Acinetobacter sp. NFM2, whose similarity rates were 100\%) and the sibling species of Veillonella (uncultured rumen bacterium and Uncultured Lachnospiraceae bacterium, whose similarity rates were $98 \%$ ) belong to strict anaerobic bacteria, which possess the function of aerogenesis and acidogenic. During the process of methaneogenic phase, Firmicutes (uncultured Firmicutes bacterium whose similarity rate was $100 \%$ and Corynebacterium sp. ICIRC105 whose similarity rate was $100 \%$ ) had methanogenic function. The results also indicated that the two-phase anaerobic fermentation of SL had achieved phase separation. The acidogenic and methanogenic microorganisms became predominant population under the regulation of different ecological factors to decrease HRT and improve the efficiency gas production.

\section{Acknowledgements}

This study was supported by International Corporation Item (2013DFG62260) and Heilongjiang Province Natural Science Fund (E2015023).

\section{[References]}

[1] Liu G Q, Dong R J, Li X Q. Biomass utilization technologies. Beijing: Chemical Industry Press, 2009. (in Chinese)

[2] Steinfeld H, Costales A, Rushton J, Scherf B, Bennett T, Hall D. Livestock Report, FAO, Rome. 2006.

[3] Cambra-López M, Aarnink A J, Zhao Y, Calvet S, Torres A G. Airborne particulate matter from livestock production systems: A review of an air pollution problem. EnvironmentPollution, 2010; 158(1): 1-17.

[4] Petersen S O, Sommer S G, Béline F, Burton C, Dach J, Dourmad J Y. Recycling of livestock manure in a whole-farm perspective. Livestock Science, 2007; 112(3): 180-191.

[5] Amann R I, Ludwig W, Schleifer K H. Phylogenetic identification and in situ detection of individual microbial cells without cultivation. Microbiological reviews, 1995; 59(1): 143-169.

[6] Muyzer G, de Waal E C, Uitterlinden A G. Profiling of complex microbial populations by denaturing gradient gel electrophoresis analysis of polymerase chain reaction-amplified genes coding for 16S rRNA. Applied and environmental microbiology, 1993; 59(3): 695-700.

[7] Aydin S, Shahi A, Ozbayram G, Ince B, Ince O. Use of PCR-DGGE based molecular methods to assessment of microbial diversity during anaerobic treatment of antibiotic combinations. Bioresource Technology, 2015; 192: 735-740.

[8] Muyzer G, Waalec D, Uitterlinden G. Profiling of complex microbial populations by denaturing gradient gel electrophoresis analysis of polymerase chain reaction-amplified genes coding for 16S rRNA. Appl Environ Microbiol, 1993; 59: 695-700.

[9] Delgado S, Arroyo R, Martín R, Martín R, Rodríguez J M. PCR-DGGE assessment of the bacterial diversity of breast milk in women with lactational infectious mastitis. BMC infectious diseases, 2008; 8(1): 51 .

[10] Shi X S, Liu D L, Lang Z H, Huang D F, Lu W, Li M. A preliminary application of PCR-DGGE in microbial community structure analysis of rural household biogas digesters. Journal of Shandong Normal University (Natural Science), 2007; 22(2): 120-122. (in Chinese)

[11] Wang Y W, Xu F H, Yuan Z Y, Song J L, Wang Q, Zhao B. Study on the methanogenic archaea communities in low temperature biogas digester by DGGE and Real-Time PCR methods. China Biogas, 2012; 30(1): 8-12. (in Chinese)

[12] Gao X X, Zhao L X, Dong B C, Wan X C, Chen L, Luo J. Experimental study on effect of separated two-phase anaerobic fermentation leachate recirculation on anaerobic process. Transactions of the CSAE, 2011; 27(10): 266-269. ( in Chinese)

[13] Dong B C, Chen L, Zhang Y H, Zhao L X, Wan X C, Gao X X. Effect of pig manure addition on biogas production of combined two-phase anaerobic digestion. Transctions of the CSAE, 2011; 27(Supp.1): 48-52. (in Chinese)

[14] Guan Z J, Li W Z, Zheng G X, Bi L P. Effect of solid-liquid separation on utilization of dairy manure. Transactions of the CSAE, 2011; 27(4): 259-263. (in Chinese)

[15] El-Mashad H M, Zhang R. Biogas production from co-digestion of dairy manure and food waste. Bioresource Technology, 2010; 101(11) 4021-4028.

[16] Marañón E, Castrillón L, Quiroga G, Fernández-Nava Y, Gómez L, García M M. Co-digestion of cattle manure with food waste and sludge to increase biogas production. Waste management, 2012; 32(10): 1821-1825.

[17] Amon T, Amon B, Kryvoruchko V, Zollitsch W, Mayer K, Gruber L. Biogas production from maize and dairy cattle manure-influence of biomass composition on the methane yield. Agriculture, Ecosystems \& Environment, 2007; 118(1): 173-182.

[18] Yue Z, Chen R, Yang F, James MacLellan, Terence Marsh, Liu Y. Effects of dairy manure and corn stover co-digestion on anaerobic microbes and corresponding digestion performance. Bioresource Technology, 2013; 128: 65-71.

[19] Demirer G N, Chen S. Two-phase anaerobic digestion of unscreened dairy manure. Process Biochemistry, 2005; 40(11): 3542-3549.

[20] Guan Z J, Li W Z, Zheng G X, Bi L P. Technology for two-phase anaerobic fermentation by solid-liquid separated solution of dairy manure. Transactions of the CSAE, 2011; 27(7): 300-305. (in Chinese)

[21] Federation W E. Standard methods for the examination of water and wastewater. American Public Health Association, American Water Works Association, and Water Environment Federation, 2005.

[22] Gao P P, Zhao L P. DNA extraction from activated sludge for molecular community analysis. Acta Ecologica Sinica, 2002; 22(11): 2015-2019.

[23] Thompson J R, Marcelino L A, Polz M F. Heteroduplexes in mixed-template amplifications: formation, consequence and elimination by 'reconditioning PCR'. Nucleic Acids Research, 2002; 30(9): 2083-2088.

[24] Wintzingerode F, Göbel U B, Stackebrandt E. Determination of microbial diversity in environmental samples: Pitfalls of PCR-based rRNA analysis. FEMS Microbiology Reviews, 1997; 21(3): 213-229.

[25] Xing W, Zuo J E, Sun Y J, Li J P. Study on microbial community in methanogenic granular sludge by FISH and DGGE. Environmental Science, 2006; 27(11): 2268-2272. 